\title{
Kenya and the Emerging Power-Shift in Global Political-Economy: Right-Wing Populism and Social Media Activism
}

\author{
Fredrick Ogenga \\ Center for Media, Democracy, Peace \& Security, Rongo University, Kenya
}

\begin{abstract}
A potential global power transition characterized by emerging economies of BRICS where China is the likely leading contender against the United States as the only global hegemon seems inevitable. The increasingly multipolar world is evidenced by the attention given to right-wing populism in Europe and USA attributed to China's aggressive approach to international trade through its stealth entry and subsequent investments in global political-economy. China's presence in Africa and Trump's America first policy's attempt to open "new business frontiers" in emerging economies of Asia and Africa in order to contain Chinese influence and threat in global hegemony are interesting happenstances that require closer scrutiny. Kenya, the biggest economy in East Africa, which is among the fastest growing regions globally, is the gateway to the East African Common Market. Historically, Kenya has a policy of non-alignment in international relations making it possible to receive FDI from both China and the US but with highly contested elections. Therefore, Kenya presents a perfect laboratory for examining the emerging power-shift in global political-economy as the country grapples with traditionally chaotic electoral power transitions and the two biggest economies in the world compete for business in Nairobi. The 2017 elections not only betrayed the international community's commitment to Western values of human rights and democracy, but also revealed the challenges of governance in post-World War II global liberalism characterized by sophisticated media institutional spaces.
\end{abstract}

Keywords: global power transition, right-wing populism, social media activism, people's assemblies, electoral justice, human rights, democracy

\section{Introduction}

A potential global power transition characterized by emerging economies of BRICS where China is the likely leading contender against the United States as the only global hegemon seems inevitable. The increasingly multi-polar world evidenced by the attention given to right-wing populism in Europe and USA can be attributed to China's aggressive approach to international trade through its stealth entry and subsequent investments in global political-economy through its presence in Africa and Trump's America first policy's attempt to open "new business frontiers" in emerging economies of Asia and Africa in order to contain Chinese

Fredrick Ogenga, Ph.D., is Director, Center for Media, Democracy, Peace \& Security, Rongo University in Kenya and President of the Peacemaker Corps Foundation Kenya. Ogenga teaches media sociology and politics at the department of Communication, Journalism and Media Studies, Rongo University. 
influence. The latter is presumably a threat in America's de facto position in global hegemony.

The strained global power relations between the US and China have been dramatized in the recent trade wars and now the outbreak of Covid-19 that Washington has described as the Wuhan or Chinese Virus eliciting anger from Beijing who have countered this narrative by suggesting the virus was planted in China by the US military ${ }^{1}$. Before the outbreak of corona virus, the US had come up openly to accuse China of unfair trade on one hand, cancelled Iran nuclear deal, and threatened to pull out of post-Cold War nuclear treaty with Russia on the other. Russia slammed the move as US attempted to be the sole superpower while China responded by reporting Washington's conduct to the World Trade Organization, a body that the US has since threatened to quit. In fact, it was not surprising that the US withdrew financial support to the World Health Organisation accusing it of mismanaging the outbreak of the corona virus pandemic and for being pro-China ${ }^{2}$. Nevertheless, as Washington strategizes to open up the US market once again post-corona, it will more likely continue to keenly observe what it now terms China's Debt Diplomacy as a ploy for Chinanization of Africa and eventually global trade takeover. In this context, the novel corona virus gives China a new lease of life in Sino-Africa relations and an opportunity to restructure Africa's debt repayment plan in order to offer some relief commensurate with the devastation the pandemic has caused to economies in Africa. Such a gesture, coupled with State open condemnation of the recent wave of black racism in China, has the potency of positioning the Asian giant as Africa's genuine partner.

Regarding Chinese presence in Kenya, the biggest economy in East Africa which is one of the fastest growing regions globally, Nairobi should trade carefully to control its Chinese debt appetite. Kenya, being the fourth indebted country to China in Africa, has been warned by Washington of unsustainable levels of Chinese debt. Therefore, Kenya presents a perfect laboratory for examining the emerging power-shift in global political-economy as the country grapples with traditionally chaotic electoral power transitions as the two biggest economies in the world (USA and China) compete for business in Nairobi - the gateway to the larger East African market. Since it has been observed that Kenya has a tradition of highly contested election, this paper argues that the 2017 elections not only betrayed the international community's commitment to Western values of human rights and democracy, but also revealed the challenges of governance in post-World War II global liberalism characterized by sophisticated media institutional spaces like social media that would remind us of the sovereignty of the people (netizens) and the importance of citizen journalism for democratic advancement.

\section{Global Power Transition: Right-Wing Populism in the US, Europe, and Africa}

This sub-section uses power transition theory perspective that predicted the rise of China in 1958 and theory of propaganda which has a lot of "fear mongering", to highlight how right-wing populism exploits differences, "us" versus "them", to instil fear by arguing of how minorities are a threat responsible for prevailing problems in countries where right-wing populism has taken root like the US. To this end, right-wing populists create a powerful narrative in the public domain that celebrate or normalize xenophobia, Islamophobia, racism, anti-immigration, and discrimination of refugees and people of colour in Europe,

\footnotetext{
1 Trump D. 2019. Come Clean: US Presses China after Corona Virus Lab Report. Aljazeera news. Retrieved 15 April 2020 from https://www.aljazeera.com/news/2020/04/trump-steps-pressure-china-coronavirus-deaths-mount-200416011036676.html

${ }^{2}$ Gawthorpe A. 2019. Trump Decision to Cut WHO Funding is an Act of International Vandalism. The Guardian. Retrieved 15 April 2020 from https://www.theguardian.com/commentisfree/2020/apr/15/trump-decision-cut-who-funding-international-vandalism-coronavirus
} 
America (Greven, 2016), and Africa. A good example of this fear was witnessed in the US where Trump vowed to block hundreds of refugees matching their way towards the US through Mexico, going as far as threatening to shoot them if they threaten American law enforcers deployed to barricade the border point to deny them "illegal entry". Right-wing populism focuses on anti-elite solidarity often pointing out, disjointedly, how the elites are responsible for the state of the affairs of the general population. It goes as far as prescribing directives meant to resist, reject, and overturn the status-quo. The latter, it is argued, would then happen through an inevitable conflict (Armageddon) and man-made calamities such as the collapse of world's financial systems. Further, right-wing populism would want to create a perception that it would be possible that conditions created by elites in their exploitation of the masses would also be countered naturally through things such as global warming and pandemics, such as the novel corona virus, that will consequently displace the status quo and therein dislodge elites from their privileged power positions.

This scaremongering agenda in public discourse is often pursued through Euro-North America-centric global configuration infrastructure that controls, information and power such as the global mainstream mass media (coloniality of information realised through the CNN and BBC effect) and global institutions such as the World Trade Organisation, World Health Organisation, International Monetary Fund and counting ${ }^{3}$. This would explain why the US withdrew its financial support for the WHO disguised as US response to the global health body's "mismanagement" of the corona virus and for being pro-China". The truth is the WHO, which is a euro-North America-centric global configuration infrastructure, acted outside the acceptable framework of this normative power configuration by being pro-China in the corona virus pandemic, something that cannot be tolerated. Nagan and Manausa (Nagan \& Manausa, 2018) in their essay titled "The Rise of Right-Wing Populism in Europe and the United States" demonstrate how the mass media is used to exploit identity issues that enable factors, among others, such as economic inequality, ethnicity, systematic corruption by the elites, or dissatisfaction with the neoliberal politics, to motivate populist trends on a global level. Identity and mass communication has greatly contributed to international political dynamics experienced today and this is why subaltern public spheres that are emerging through social media and citizen journalism are worth appraising because they provide alternative avenues for citizens to express themselves, reject prescribed elitist power structures, challenge dominant views and reclaim the popular will of the people.

The latter, as we shall see later, is what has led to the latest clamour for a referendum in Kenya under the Building Bridges Initiative popularly known as "The Handshake" between the incumbent President, Uhuru Kenyatta and his arch Rival and opposition leader, Raila Odinga, after a highly controversial presidential election in 2017. Odinga declared himself "The People's President" and held a parallel swearing in after Uhuru Kenyatta was declared president elect in the controversial 2017 elections. The handshake is considered a deal between equals in Kenya's political enterprise where Odinga represents the ordinary people as the President and Uhuru as the President and head of State albeit not elected by supporters of Odinga.

In this context, local and global power and power transition is viewed in relation to the concept of Cartesian dualism ${ }^{4}$ such that in Kenya's local power transition, Odinga and Kenyatta (the hegemon and the challenger or the likely successor) inherits these subjective positions almost naturally. In the context of the 21 st century, the US is considered as the only hegemon and the emergence of BRICs ( Brazil, Russia, India, and

\footnotetext{
${ }^{3}$ Nyere, C. 2020. A Decolonial Perspective on The North Atlantic Treaty Organisation's Invasion of Libya in 2011. Pretoria: Thesis The University of Pretoria. South Africa.

${ }^{4}$ See internet encyclopedia of philosophy on https://www.iep.utm.edu/descmind/
} 
China and South Africa) as the competing challenging force where China is considered the likely main contender or successor (Feng, 2013). In the theory of power transition, it is argued that what will determine a peaceful transition in Sino-US relations will depend on the perceived similarities and level of convergence at the economic, political, and security spheres of influence (Feng, 2013) between the two biggest economies in the world. The bromance between China and the US is arguably on a level of economic cooperation and this is why they seem to have so far succeeded in getting along, recent trade wars notwithstanding. However, experts are warning that this holiday may not last long, especially with the emergence of the "Wuhan" virus, until the two countries find a way of mutually cooperating in politics, security and even health and environmental spheres of influence. In Kenya, Odinga and Kenyatta shook hands in front of the global media and resolved to work together and so far Kenya has gained politically and economically. Could this be the option for China and the US post Covid-19? The recent truce between Trump and Xi on halting new tariffs for 90 days as they negotiate a lasting agreement is considered a temporary measure by many experts that cannot resolve the serious rivalry problems between the two economies. Bloomberg reported that:

An easing of tensions on trade could ease gains in the US dollar and boost riskier assets including emerging markets currencies and stocks, though investors and analysts agree that the US and China are trying to fix a long-term problems that cannot be solved in one dinner. ${ }^{5}$

This is the trajectory that informs the current wave of right-wing populism both in Europe and Africa as the US re-strategizes with allies in Asia pacific and Africa to contain Chinese influence or threat. Regarding Kenya's position in this relations, a conclusion can be made of a country caught between a hammer and the anvil characterized by a sophisticated geopolitical power dynamics as it strives to balance and benefit from its non-aligned foreign policy, receiving business from both the left side of its arm (China) and the right side (the US) asserting itself locally as the East African hegemon. This struggle is often witnessed during highly contested Presidential elections, with America playing a conspicuous role of seeking to maintain the status-quo in pursuit of its own interests. The US often harbours the fear that regime change in Kenya might instil a leader who is not happy with the prevailing bi-lateral relations and consequently interfere with US strategic interests in Kenya and the broader East African common market. Interestingly, China follows a policy of non-interference with domestic affairs of a partner State.

The US-China rivalry plays out openly in the international media and escalates through threats regarding trade routes and disputed territories in the South China Sea. Perhaps the surest likelihood of conflict emerges from Trump's biggest complain about Chinese trade practices centering on intellectual property theft, non-tariff barriers, and cyber theft ${ }^{6}$ which makes conflict somehow inevitable going forward. But are we likely to see full blown conflict between China and the US? Power transition theories predict war when superpowers are close in power and peace when power predispondence exists. Feng argues that power parity needs to be considered in the context of common interests and preference of superpowers. Conflict abates when the nation shares fundamental rules of the game in world affairs. Feng identifies four historical modes of transition: co-dominion, deterrence, confrontation, and co-operation. Of the four historical transitions, each time the challenger surpassed the hegemon in economic power, where China is said to be steadily approaching ahead of the US,

\footnotetext{
${ }^{5}$ Bloomberg News, Trump-Xi Meeting: Trump Xi Agree to Days Tariffs Cease-Fire to Contain China Trade War. Investor Business Daily. Retrieved on 10th December 2011 from www.Investors.com.

${ }^{6}$ Bloomberg News, Trump-Xi Meeting: Trump Xi Agree to Days Tariffs Cease-Fire to Contain China Trade War. Investor Business Daily. Retrieved on 10th December 2011 from www.Investors.com.
} 
deterrence and confrontation by the hegemon against the challenger did not prevent the challenger from assuming global leadership in the long term.

Among the newly rising nations (BRICS) as pointed out earlier, China is presumed to be the potential contender of world leadership. Feng further argues that the economic and financial interdependence between US and China is the force that currently shapes their relation and would further shape their political arrangement necessitating coordination and cooperation in policy issues. However, Feng warns that this is not sufficient for a peaceful transition until their political and security relations are solidified and preference coalesced substantively. Feng (2013) notes that "it can also be emphasized that their relations with other countries (such as Kenya) and their respective overseas interests will also define the nature of transition, if there is one in the 21st Century (Salman, 2017; Woosang \& Scott, 2015; Levi, 1987).

Kenya promulgated an ambitious constitution in 2010 that promised to change among other things to protect freedom of expression and political participation regarding leadership and governance. A reality that has shaped domestic politics and eventually, Kenya's relations with friendly nations in the global political-economy, particularly the US and China as Washington and Beijing compete for business in Nairobi. The latter being the financial capital of the East African Community common market. This explains the reason why President Donald Trump has named Kenya as one of his foreign policy "anchor countries" (Andae, 2018) in the region as US seeks to enhance relations with Kenya and other African countries viewed as regionally important but at the same time prime targets of China's move to gain political and economic advantage in the continent.

\section{The 2010 Constitution: The People Are Sovereign}

The Constitution of Kenya protects freedom of expression and freedom of the press, including the right to receive and impart information under Article 33 and 35. But media crackdown in the aftermath of the 2017 elections that saw mainstream television channels shutdown for more than one week was a threat to freedom of expression and a direct violation of the constitution. All this was done by the government in a bid to contain a situation emerging out of a prolonged electoral crisis whose results were rejected by the opposition on the 8th of August 2017 spilling into 2018, subjected to a Supreme Court of Kenya ruling that nullified it, prompting a fresh one on the 26th of October 2017. The fresh elections were largely boycotted by the opposition and upheld by the same SCOK setting precedence for a chaotic jurisprudence that left the country in a crisis. The Daily Nation newspaper, a subsidiary of one of the stations that was shut down by government, the Nation Television, for example, reported the media shutdown in a headline titled: "Switch-off a Throwback to Dark Days of the Past" that expressed their disappointment by the move. The paper argued that:

While Kenya has one of the freest media spaces on the African Continent, it has intermittently faced repression from the government... In the 90 's the government had an atrocious reputation as a muzzler of the press...the free press of 1994 criticized the government of what it called blatant harassment and persecution of journalists through relentless abuse of the legal machinery and use of police.7

This was happening in the advent of multiparty democracy and one would have expected that 17 years down the line, the media would have advanced the democratic culture in the country given that Kenyan ushered in a new constitution in 2010, after the controversial 2007 elections that led to the deadliest post-election

${ }^{7}$ Kimanthi, K. 2018. Switch-off a Throwback to Dark Days of the Past. Daily Nation Thursday 01, Kimanthi Kennedy, 2018. 
violence in the country where more than 1,000 people died and several others displaced, with much expectation, promise, and hope. Sadly, the country seemed to be eroding back to dictatorship judging by the-State sponsored media crackdown during the 2017 elections. Mainstream TV stations were switched off by the Communication Authority of Kenya to prevent Kenyans from watching live, the coverage of the swearing in of opposition leader as "The People's President" citing security concerns.

Even though the ban was challenged at the High Court which revoked the decision, the government ignored the ruling. This paper argues that the conduct of the government in the 2017 elections characterized by fraud, violence, and human rights abuses coupled with intimidation of the judicial system and media shutdown, left Kenya in a volatile situation regarding its democratic experiment. Corruption and inequality makes citizens dissatisfied with neo-liberal politics witnessed in the wholesale election boycott in the 2017 fresh elections as ordered by the Supreme Court of Kenya. Nevertheless, the lessons learnt by the violent nature of Kenyan elections characterized by ethnicity require that a concerted effort is made to solve its root causes. Overtly, it may appear as if it is tribal politics but when covertly or critically examined, violence usually flares-up every electoral cycle due to electoral injustices. This is where right-wing populism is witnessed as the State exploits ethnic differences to instil fear in order to maintain the status quo at the expense of civil liberties.

Such State actions call for a more independent and robust truth telling African media or media in Africa that is free from state influence and control unlike the current media enterprise that is vulnerable to political and economic manipulation - the composition of this envisioned media is a subject of controversy in media scholarship and therefore beyond the scope of this paper. However, in an environment where the media is largely influenced by the state, citizen journalism has become popular replacing traditional journalism through social media spaces that represent the "will of the people". In such instances, the paper further argues, social media becomes the avenue and space through which Kenyans engage in uncomfortable discussions that could make them reap their democratic dividends and, at the same time, expose the double standards and hypocritical nature of elites in Kenya and their European and American counterparts in global human rights discourses championed through 'democracy'.

The fact that Kenyans are increasingly relying on social media is written on the wall. Even though privately owned media is quite visible and robust, its role is increasingly becoming questionable through its relations with elite politicians and businessmen who influence its agenda through propaganda and cannot be the trusted alternative voice. In assessing Kenya's quest for electoral democracy, it appears the constitution was prematurely celebrated by the political class. The constitution is often applied selectively, without understanding what constitutes constitutional democracy. Constitutional democracy is about respect for independent State institutions that mutually co-exist to drive governance. The latter seems not to be case in Kenya since the most crucial state institutions such as law enforcement, the legislature, and the judiciary appear to be under state capture by the executive. In fact, these are some of the questions that are coming up in the current clamour for a referendum.

It is important to remember that in 2013, Kenya equally had a hotly contested election that was petitioned in the SCOK where it was ruled that Uhuru Kenyatta was validly elected, a decision that was not well received among the local and international jurisprudence enterprise. However, the ruling paved way for more advanced jurisprudence in 2017 that encouraged The Supreme Court of Kenya to make a historical ruling that nullified the election of a sitting President ordering fresh election to be conducted in strict conformity with the law which, as it has been pointed out, the opposition boycotted. Nevertheless, this landmark ruling was further 
watered down when the same court failed to hear a crucial case a day before the repeat presidential elections on the $26^{\text {th }}$ of October 2017 regarding the legality and the implications of opposition's withdrawal after the court failed to raise a quorum, allegedly, due to State (executive) intimidation.

Unfortunately, the quorum issue was superficially covered by the mainstream media. Whereas media should play a more proactive than reactive role in the electoral process, the local mainstream media seems to be a victim of political, economic and cultural structures that will continue to define its mod us-operandi for a long time to come. For example, the media played around populist credential of Uhuru Kenyatta presenting him as the most preferred candidate and the best leader that Kenyans deserved, corruption allegations, ethnicity, and nepotism bedevilling his first term notwithstanding. Media campaigns centred on propaganda and fear mongering instilling ethnic fear about a Raila Odinga presidency by virtue of his ethnicity. Being Luo , the media fell short of asserting that Raila would seek revenge to the Kikuyu community if given power due to historical rivalry among the Kikuyu and Luo tribes dating back to post-independent political sins of their fathers who assumed Kenya's leadership after Kenya gained self-rule. Soon after independence, Raila's father became Deputy President and Uhuru's father became the first President in a relationship characterised by loyalty and deceit leading to the famous house arrest of the former and planting the first seed of bitterness between the two communities. Thereafter, Luos have remained in-opposition politics to date.

In addition, the issue of the Standard Gauge Railway funded by China under China's Belt and Road Initiative (BRI) that featured prominently in the media with critics weary about its economic viability compared to the hundreds of billions borrowed from China for its construction is a testimony of continuous disagreement and polarization between the ruling party and the opposition on economic policy issues on how Kenya should develop. There was a lot of secrecy and misinformation, including propaganda, regarding the actual cost of the SGR project largely because it was viewed as the State's pet project. The mainstream media did little to unmask the controversial project funded by tax payers in order to guarantee local participation and support compelling Washington to warn Nairobi about unsustainable levels of loans from China and to be weary of China's debt diplomacy.

In a December 13 speech, the US national security adviser John Bolton placed a Cold-War-style competition between Washington and Beijing at the centre of Trump's new strategy in Africa by suggesting that African states are being misled by China's offers of hefty loans for infrastructural projects. By luring African governments into debt traps, Bolton warned that the Chinese regime is actually aiming to foster dependency relationships as part of its quest to achieve global dominance (Kelly, 2018). In this context, the US struggles to present its support for Africa as socially positive in contrast to what is presented as China's indifference to corruption, environmental and human rights standards, exemplified in China's handling of the corona virus outbreak, yet the US itself is often guilty of supporting many governments with significant problems regarding repression and corruption like Angola.

And now the US appears to be laying down the rules for a zero-sum game, in which African countries are given the choice of siding with either Washington or Beijing. (Kelly, 2018, p. unspecified)

Therefore, the role of media institutions in configuring global power relations cannot be taken for granted and that is why this paper argues that the conversation should now shift from news content about what is being represented, and the inherent bias, to discourses about media's ecology, locality, diversity and plurality found in a more diverse media ownership landscape and what this means for electoral democracy in Africa from an 
ontological perspective - this is the refreshing environment brought about by social media and User Generated Content discussed later.

\section{Right-Wing Populism, Propaganda, and the Mainstream Media}

Kenya has arguably the most advanced media ecosystem in East Africa and boasts several private media ownership. The only problem is that the media in Kenya has diversity issues due to ownership factors (Ogenga, 2008). Most of the media in Kenya is owned by businessmen with political influence. The main challenge in this environment is that these media owners virtually come from two main ethnic communities in Kenya and minimal foreign ownership raising questions of editorial bias and partisanship in political reporting. The main media institutions are basically owned by four media groups: Royal Media Services, Nation Media Group, Standard Group and Star Times Limited. The first two groups are largely owned by Kikuyu elites while the last group is largely foreign owned by the Chinese, a reality that influences the approach they adopt in their political coverage and daily programing.

It is interesting to point out how the media was excited in 2017 while declaring Uhuru Kenyatta the President elect only to cry wolf barely three months after his swearing in that his government is orchestrating media shutdown. However, the State did this in order to gate-keep the nature of information meant for public consumption and it is in such instances that propaganda plays a big role. The media began propagating legitimacy issue regarding the elections by blowing congratulatory messages to the "president elect" out of proportion. To keen observers, no amount of congratulatory messages from the US, the UK, and neighbouring countries (Uganda, Rwanda, Burundi, and Tanzania) would sanitize the fraudulent nature of the 2017 elections as exposed by the SCOK evidenced through information that was circulated on social media.

Burundi became the first East African country to congratulate Uhuru Kenyatta for obvious reason. Burundi borrowed Kenya's electoral equipment in their last general elections to perpetuate fraud that help propel Pierr Nkurunziza to power in controversial elections that sparked weeks of protests and violence. Rwanda followed suit in congratulating Kenyatta in the context of Paul Kagame's re-election in a walk-over process that gave him a landslide victory after amending the constitution to extend the country's presidential term limit. The case of Uganda, which was the third East African State to congratulate Kenyatta, is a well-known case of a leader with little tolerance for the opposition in a country where elections take place to rubber-stamp and justify Yoweri Museveni's long overdue grip on the presidency. East Africa's leadership is a case of birds of the same feathers, with little tolerance for the opposition, misguided determination to take the region back to the age of African dictators who disregard human rights and the rule of law hoping that such leadership is the guaranteed road-map to development in the region - such propaganda should really worry everyone.

\section{Propaganda and the 2017 Post Election Violence}

It is well known that the media set agendas (McCombs, Shaw, \& Weaver, 1997; Graber, 2000) and use values such as prominence (journalists quoting renowned public figures when reporting) to satisfy the interests of the public. Right-wing populism and fear mongering manifestations were clearly visible through ethnicity in the 2017 presidential elections prompting the opposition, human rights groups, and other stakeholders to accuse the government of ethnic profiling. The State seemed to be targeting and profiling members of the Luo community based on how many of them were brutalized and killed in the name of quashing "illegal 
demonstrations" during spontaneous protests in the aftermath of the 2017 controversial general elections. The media used propaganda when reporting post-election demonstrations terming them "Luo Mass Action".

Consequently, when repeated presidential elections failed to take off in many counties in Kenya due to the opposition candidates' (Raila Odinga) boycott citing failure of the electoral body to meet their conditions on minimum reforms, Independent Electoral Boundaries Commission (IEBC) seemed to read from the same ethnic-profiling-script wherein, ruling coalition politicians singled out counties in Nyanza (Luo counties) as the only counties deserving repeat presidential elections despite the fact that many other polling stations in several counties in opposition strongholds failed to open. The IEBC failed to include counties in Coastal Kenya, Western Kenya, and Lower Eastern (which equally boycotted elections) in the list of its planned repeat of repeat elections despite the fact that no voting took place in those counties. In fact, a day following this profiling, violence broke out in non-Luo counties like Bungoma County in Western Kenya occupied by the Luhya community.

These events invited criticism from different stakeholders regarding State-sponsored violence against members of the Luo community that received global media attention. Social media had campaigned hash tagged "Luo Lives Matter" carried out in major cities like New York and London against police brutality in parts of Kenya (Kisumu, Siaya, Homa Bay, and Migori) featuring among others, Kenya's only Oscar Winning Hollywood celebrity, Lupita Nyong'go. The 2017 elections and the attendant chaos demonstrate clearly how elites in Kenya exploit identity issues through propaganda and the naming or blaming of others (othering) to incite violence and human rights abuses for their own benefit. The 2017 media shutdown should be a turning point for the Kenyan media regarding its watchdog role. It also points out the important role played by other institutions such as the judiciary, the legislature and law enforcers in democratic consolidation. The judiciary could have used the public confidence gained after the Supreme Court of Kenya's Ruling that nullified Presidential election, but squandered the opportunity by not ensuring that the conditions for fresh elections were strictly adhered to. This is arguably a big setback since public institutions such as the courts and Parliament have never won the confidence of the country for obvious reasons related to corruption.

The media failed to appreciate the importance of the 2017 electoral dispute, and and just like in 2007, it applied Cartesian dualism, reducing it to a two-man affair (Uhuru Kenyatta and Raila Odinga), wherein, Raila was projected as a perennial looser while Uhuru was projected as a "digital president". The Building Bridges Initiative or famously known as the handshake ${ }^{8}$, which is now enjoying local and international support came as a big relief for many Kenyans because it brought an opportunity for reconciliation and peace. This gesture is what has now pushed the Africa Union Commission to appoint Raila Odinga as a Special Envoy for Infrastructural Development in the continent. In 2017, the mainstream media simply became the mouthpiece of the Independent Electoral Boundaries Commission (IEBC), which was in turn the mouthpiece of the Jubilee Regime with netizens describing it as JEBC (Jubilee Electoral Boundaries Commission), until it was shut down by the State for defying orders not to cover the live swearing in of the People's President, Raila Odinga on the 30th of January 2018 in a well-attended public gathering dubbed "People's Assembly" at Uhuru Park or Freedom Park.

\footnotetext{
${ }^{8}$ Raila Odinga and Uhuru Kenyata surprised the nation and the world by the famous handshake on the 9th of March 2018 after resolving to work together to solve ethnic antagonism, corruption, electoral conflict, marginalisation and inclusivity. On the 14th of December 2018, the two were awarded a honorary degree for their leadership that led to the peaceful action resolution of political conflict in Kenya by the Jaramogi Oginga Odinga University of Science and Technology.
} 


\section{Media in Favour of the Status-Quo}

The media's agenda was in favour of the status-quo owing to two reasons. The Kenyan media is largely owned by political elites and therefore, the two would inevitably speak the same language on issues of mutual interest. Generally, news coverage of the ruling coalition presidential campaigns were characterized by details that emphasized on numbers wherein, long wide shots, panoramic shots and high angles, reminiscent of the "tyranny of numbers" philosophy that helped propel the Jubilee coalition into power in a highly contentious general elections in 2013, were used. In this context, Jubilee Party was projected as the most popular party in the country enjoying "massive following" and the party to beat, yet things on the ground had heavily shifted in favor of the opposition in ways that should have warned the ruling coalition.

Contrarily, media's coverage of the opposition coalition, the National Super Alliance (NASA) was characterized by close-ups, punctuated by occasional poor audio quality, with limited attempts to show-case the magnitude of their usually charged supporters in rallies and political gatherings christened People's Assemblies. This stark difference in coverage incited questions on media objectivity and impartiality as fundamental values of the journalistic profession in democratic societies. The only logical justification that would account for why all privately owned stations in Kenya sometimes display similar news content during elections in terms of how they have been narrated and edited would be that they are probably sourcing stories from one central agency or unit that has more news access privileges, and therein, betraying the concept of media diversity and plurality as crucial ingredients in democratic consolidation and important elements in media development in Africa.

Of course the August 8, 2017 election was largely peaceful but controversial, forcing the opposition to challenge the re-election of President Uhuru Kenyatta by filing a petition it the highest court of the land-Supreme Court of Kenya. The latter ruled in favour of the opposition prompting the IEBC to organize fresh presidential elections on the 26th of October 2017 in a move that damaged the reputation of Foreign Observer Missions that included the Africa Union, the East African Community, the European Union, the Carter Centre and others. It is important to note that the Kenyan media, quoting from official sources, extended the false narrative echoed by the Foreign Electoral Observer Mission that the opposition should concede defeat owing to the false belief that elections were peaceful, free, and fair. It is this false narrative that the SCOK helped to counter through its bombshell ruling, a first of its kind in Africa, nullifying the re-election of a sitting president. The 2017 controversial elections in Kenya and the violence that ensued have complicated regional transitional politics with many observers pointing out to the failures of EAC, the EU, the AU, and the Carter Centre to be neutral players in their quest for human rights and democracy on the continent amid state sponsored violence and human rights abuses in the name of quashing illegal protests in the country that left a significant number of youth dead mainly in opposition strongholds. In this context, social media emerged as a subaltern counter public speaking against human rights abuses by supporting alternative voices such as those that advocated for peoples' assemblies. The latter were already declared illegal by the state but remained largely active virtually that face to face.

\section{"Virtual" People's Assemblies}

The concept of "People's Assembly" was introduced by the opposition coalition, National Super Alliance (NASA) after they rejected the results of the August 8, 2017 presidential elections that declared Uhuru Kenyatta the winner. NASA categorically stated that those elections results were manipulated to give Uhuru Kenyatta a computer generated victory. The most salient issue about the assemblies is that they remained 
predominantly virtual as most of what was actualized was related to the legality of the assemblies which largely depended on their approval by County Assemblies in opposition strongholds. Before the assemblies were called off to pave the way for dialogue, more than 15 opposition counties had approved them. The momentum of the assemblies was therefore sustained virtually on social media where they enjoyed a universal approval rating especially among Kenyans in the opposition. So what were People's Assemblies? The "People's Assembly" borrows from Article one of the Kenyan Constitution ${ }^{9}$ which details the sovereignty of the people in the following manner

Sovereignty of the People

(1) All sovereign power belongs to the people of Kenya and shall be exercised only in accordance with this Constitution.

(2) The people may exercise their sovereign power either directly or through their democratically elected representatives.

(3) Sovereign power under this Constitution is delegated to the following State organs, which shall perform their functions in accordance with this Constitution-

(a) Parliament and the legislative assemblies in the county governments

(b) The national executive and the executive structures in the county governments and

(c) The Judiciary and independent tribunals

(4) The sovereign power of the people is exercised at -

(a) The national level and

(b) The county level.

When the assemblies were being launched in opposition strongholds, the government dismissed them as inconsequential. However, the amount of attention they received through media coverage, especially on social media, generated interest nationally and internationally in compelling the government to opt for dialogue. The assemblies attracted hundreds of thousands of Kenya who assembled to hear their leaders and voice their concerns directly, more often, directing their leaders on what to do. The surging numbers every time NASA called for an assembly before they were declared illegal, became a good reason to worry the government. The former Attorney General, Githu Muigai openly questioned the legality and constitutionality of the People's Assemblies to the extent of filing a case at the High Court that has never been given full hearing. High Court judge, Chacha Mwita referred the case to the SCOK claiming it raised weighty issues of the law that can only be determined by the Chief Justice.

This paper further argues that it is through the well organized and successful People's Assemblies, in a predictable timetable that culminated into the 30th January 2017 well attended swearing in of the People's President (Raila Odinga) at Uhuru Park that gave the regime sleepless nights. The assemblies have given Kenyans closure about their right to exercise the sovereign power under Article One as "the People" directly as envisioned by the Constitution bringing an end to political dictatorship. It is the sustained pressure from the assemblies that later transformed into Building Bridges Initiative following the famous handshake by President Uhuru Kenyatta and his challenger Raila Odinga on the 9th of March 2018. Well, the state blew hot and cold regarding the swearing of Raila Odinga as the People's President. For example, the State over-reacted by shutting down mainstream television stations as earlier noted in a move that was widely condemned by several stakeholders. The United States and the European Union released statement that betrayed their neutrality in

${ }^{9}$ Constitution of Kenya 2010, p. 12 
Kenya's elections after the media shutdown:

The US Department through its department spokesperson Heather Nauert said it rejects actions that undermine Kenya's Constitution and the rule of law...Uhuru Kenyatta was elected president on October 26, 2017 in a repeat poll that was upheld by the Supreme Court. Grievances must be resolved through appropriate legal mechanisms

The European Union, in a statement on its website on Thursday, said...Kenya's election year is over, and the challenges laid bare by the electoral process will have to be addressed. All actors should contribute to calm.

The US also urged Kenyans to have a "national conversation to build cohesion and address long-standing issues", while the EU called for unity and said: "The Kenyan people now have the opportunity to take the country forward and work together on their historical path towards democracy and development."10

Even though the US was in favour of the status-quo, they were compelled to issue a powerful statement regarding media shutdown that seemed to have not only touched on civil liberties but compromised the euro-North America-centric role of the media as a critical institution in global power configuration, again a reality that was unacceptable in Washington because it touched on the very foundation of the American society (liberty).

\section{US, EU, and Right-Wing Propaganda}

Although the US and the EU urged the government and the opposition to respect the constitution by condemning the media shutdown and the swearing in of the People's President respectively, it was too little too late. This paper avers that the interpretation of the constitutionalism or otherwise of the "People's Assemblies" should have been left for the Kenyan Judicial enterprise. Kenya has a team of highly trained and qualified professional lawyers, most of who actually drafted the 2010 Constitution, and attempts by the US and EU to criminalize their interpretation as illegal and unconstitutional amounted to neo-colonialism and interference with Kenya's sovereignty (coloniality of knowledge, an epitome of Euro-North America-centric epistemological monopoly) ${ }^{11}$. Perhaps this explains why China is increasingly becoming a favourite investor in Kenya because the current crop of corrupt leaders would not want to be held accountable and China gives them that opportunity since they are hardly concerned with internal politics of the country. This should not be good news if China were to become the new global hegemon. Nevertheless, for many Kenyans, the partisan actions of the EU and US deserved strong condemnation.

The US and the EU were guilty of supporting shambolic and flawed elections in 2017 because of their own economic interests that seek to expand their empire in the West's renewed appetite for emerging economies globally following the domination of China in African affairs (coloniality of power exercised through control of the global economy) ${ }^{12}$. The Kenyan story left observer missions dusting-off their soiled reputation as defenders of human rights and democracy in Africa. Nevertheless, America's "lead from the back" approach under Barrack Obama, transforming into "America first" policy under Donald Trump has given birth to the most sophisticated trade wars of the 21 st century between China (the challenger in global power transition) and the US (the hegemon) (Feng, 2013) and led to a disjointed global co-operation against the corona virus pandemic.

${ }^{10}$ Nation Reporter 2018 US and EU Criticise Raila Oath, Call for Respect of Law DN Friday February 2, 2018.

${ }^{11}$ Ibid

12 Nyere, C. 2020. A Decolonial Perspective on The North Atlantic Treaty Organisation's Invasion of Libya in 2011. Pretoria: Thesis The University of Pretoria. South Africa. 
As the US retreats from its global leadership role as a defender of human rights and democracy, gaps are emerging whose consequences a visible in the current global response towards the Covid-19 pandemic. In the 2017 controversial elections in Kenya, the US betrayed its position in Kenya's political-economy as a born again capitalist (taking sides openly). The entry point in this respect would be to baby-sit a rogue and puppet regime, irrespective of its human rights record and democratic credentials, in a bid to protect the status-quo that would guarantee them space to expand their business empire evidenced in the newly signed multi-billion dollar deals when Trump hosted Uhuru Kenyatta at the White House in Washington in October 2018. The deal includes the construction of a superhighway from Mombasa to Nairobi that many economists have questioned its commercial viability given that China has already finished constructing the controversial Standard Gauge Railway line from Mombasa to Nairobi whose economic benefits are yet to break even. In Trumps administration "Prosper Africa" approach, "The white House may wish to make a close African ally such as Kenya an example of the rewards of working closely with the US, but it is not able to shower its friendly countries with largesse" the way China has done (Kelly, 2018, p. unspecified ).

In addition, China might be conveniently absent from Kenyan Affairs especially on issues of human rights and environmental sustainability but the US's support for questionable regimes in Africa as witnessed in their decision to back the re-election of Uhuru Kenyatta in the 2017 through questionable Election Observer Missions like the Carter Center does not help Africa's prospect for greater democracy. Such a decision was Washington's calculated attempt that used propaganda to gag independent State institutions such as the judiciary (that was highly intimidated) to sanitize fraud, rationalize what the opposition termed as a computer generated victory, and buy the consent of the people by selectively invoking the rule of law at the expense of genuine quest for justice, human rights and democracy in order to maintain a friendly regime in Nairobi.

Submission to the law should not be selective, it did not help for the US and EU to lecture Kenyans about the thresholds of "political law and order" (Euro-North America-centric epistemological monopoly) especially when it became clear of how they contributed to manufacturing the crisis. The US, for strategic reasons, remained silent about manipulated figures, State sponsored violence that targeted opposition protesters. Instead of objectively intervening, it joined jubilee sycophants calling for a national dialogue about development, an idea that seemed to have carried the day. Could the US be slowly learning from China on African Affairs for competitive advantage? President Uhuru Kenyatta's Big Four legacy agenda that everyone, including Raila Odinga, is now supporting emanates from the post-election semi-structured dialogue on development as pushed by the US.

\section{Social Media Counter-Public and the 2017 Controversial Elections}

The mainstream local media in Kenya leaned towards the ruling coalition compared to the opposition in representing the 2017 general elections, more so, in their coverage of presidential campaigns. This reality incited a fundamental question. Did such coverage have any substantive political implication in swaying public opinion in the country? Is it true that the media can sway voters as it happens in established democracies? The answer to the first question is yes. In the Kenyan elections, the media was an accomplice to a well-orchestrated plan by the political and economic elites in Kenya to retain the status-quo. The answer to the second question is both yes and no. No, because ethnicity is a big determinant of voting patterns in Kenya and yes, because judging from an election that was rejected by more than half of Kenyans by virtue of the evidence that circulated on social media regarding malpractices, it was difficult to understand why a significant number of 
Kenyans (those who voted for the ruling party) still believed their candidate won fairly and that the elections were, in fact, free and fair if it was not for media bias.

The media tended to cover views that are supportive of the status-quo implying that a section of the audience was being treated to media propaganda. Nevertheless, the fact that there were irregularities was evident when the opposition demanded that they be served with forms 34A's that reflects presidential results from the constituency level some of which the IEBC failed to provide. These irregularities, according to the opposition, were evident in the electronic streaming and tallying of presidential results that did not emanate from verified signed forms 34A's as stipulated in the Constitution. According to the Kenyan Constitution, and following the Court of Appeal ruling in the Maina Kiai case (the case concerned the finality of results declared at the constituency level), presidential results are declared at the constituency level after tallying and verification in the presence of party agents who must sign in agreement. This did not necessarily happen as required.

It is argued by many observers that the IEBC worked backwards in its electronic tallying to achieve a pre-determined electoral outcome that maintained an 11 percent margin between competing political contenders including those competing for president. The opposition rejected the presidential results and refused to concede defeat citing parallel tallies that showed Raila Odinga won. The opposition argued that the IEBC's database was hacked by Jubilee Party luminaries and numbers manipulated in favour of Uhuru Kenyatta. They went ahead and displayed evidence of log-ins from the hacking and produced a printed document of presidential results leaked from the IEBC database by a protected source, that went viral, showing how Raila Odinga won the elections. These are the figures they used to swear in Raila Odinga as the People's President. Such developments emphasize the emerging active role of social media in the absence of an objective mainstream media as a tool for alternative political opinions. It is important to note that the mainstream media was criticized by many Kenyans including one prominent celebrated media personality, Fred Obachi Machokaa, on social media. See the critique that follows appearing on Facebook:

My media friends and colleagues...mmetu-let down haki!!! [you have really let us down] No critical questions asked of IEBC to help calm the nerves of millions of Wananchi [citizens] who obediently voted and went home as ordered. Funny analyses by people clearly on a mission to please whichever side they support. The media received and displayed results without cautioning viewers that the results were provisional. The media didn't even remember to ask where the results were coming from only for IEBC to tell the viewers too late? And now we keep on listening to analysts saying nothing for 48 hours as if since election time, nothing else is happening to the country...sad. ${ }^{13}$

In the context of the foregoing electoral controversies, at least in the court of public opinion through social media on whether Kenyans were receiving genuine streamed results or fraudulent ones, the opposition sets up five conditions to the IEBC for conceding defeat that the IEBC brushed aside. These conditions were:

1. That the National Super Alliance (NASA) did not declare Raila the winner

2. That the IEBS stops forthwith in streaming fraudulent results

3. That the IEBC opens up its database to various stakeholders for scrutiny and verification as required by law and in the spirit of public access to information;

4. That the IEBC declares Raila Odinga and Kalonzo Musyoka the duly elected president and vice president of the Republic of Kenya respectively.

${ }^{13}$ Fred Obachi Machokaa, Facebook, August 11 2017, 6:06 PM. 
The elections ended dramatically after the opposition refereed the verdict in the court of public opinion (citizens) to decide on the direction the country ought to move following the bungled elections sparking days violent protests. One important issue echoed by Machoka ${ }^{14}$ is how the media switched off to normal broadcasting mode censoring the violent protests across the country despite the fact that international media was awash with violent post-election scenes. The contention is that the media was biased in its coverage of the electoral process, especially the tallying and streaming of the results, judging from how they censored opposition voices disagreeing with the tallies.In fact, the media ended up representing two celebrating communities by covering Uasin Gishu and Kiambu Counties after IEBC declared the winner at the expense of other Counties in the country that were rocked with violent protests almost immediately. Whereas such coverage may mean less due to the fact that Kenyans vote along ethnic alliances, they should not be taken for granted for it is well known of how the media can be used for spin doctoring and propaganda to sway public opinion, in this case, in support of fraudulent and bungled elections.

Consequently, before the SCOK was petitioned, two competing narratives emerged in the mainstream and social media, those that are supportive of the regime versus those that seem to question the validity of the declaration by the IEBC that Uhuru Kenyatta won the elections. Interestingly, it appears as if evidence was being produced on social media that was not available on mainstream media, a reality that transformed many audiences. Consequently, many Kenyans switched from mainstream media to social media. One such evidence came from a veteran mainstream reporter Larry Mdou's comments on twitter regarding electronic tallying of the presidential results which stunned many observers due to the fact that it continued to tally days after the elections were over. The results showed Uhuru Kenyatta still in the lead and voter turnout surpassing the actual number of those who voted. Mdou commented on his twitter handle that: "The numbers [votes] still increasing, in one of the enduring mysteries of our time" ${ }^{, 15}$ igniting an online Twitter and Facebook reaction on possible theories that could explain the increasing tallies of presidential votes days after the elections were long over.

Keen observers invoked African narratives related to the fear of death "ontological fears" and the curse that befall those in society who harm or kill others for they get haunted and invite death upon themselves. There was public suspicion that IEBC ICT manager Chris Musando who was crucial in the entire functioning of the electoral technological infrastructure was killed, his finger chopped and used, within 24 hours that the cells were still alive, to access the IEBC database in order to manipulate results in favour of Jubilee Party. Therefore, since the body cells could only survive for 24 hours, there was no way of logging out of the system unless the software running the programme was completely destroyed. See the following excerpt from Facebook:

There is no way they can stop that system of IEBC from counting, increasing the tally. Let me educate you of what you may not be knowing when a person dies, it takes around 24 hours for all body functions to stop completely... when they took Musando's finger, they used 24 hour to log-in the system, set the generated logarithmic then logged out, its called use of electromagnetic cells, since Musando had set it that he was the super admin and such roles were completely his, that other duties he had delegated to his juniors, no one can manage to stop it [the IEBC computer tallying system], unless Musando resurrects, or they completely destroy the software. Then an idiot will come to me and say that Jubilee won. ${ }^{16}$

\footnotetext{
${ }^{14}$ Fred Obachi Machokaa, Facebook, August 11 2017, 6:06 PM.

15 Madouwo, Facebook. 14th August 2017. https://public.rts.iebc.or.ke/results/results.html.

16 Brian Keverenge Ung'iya, Facebook post. 14 August 2017, 12:24 PM.
} 
The validity of such claims is of course still contested in the court of public opinion but they echo the protest made by the NASA opposition that the IEBC database was hacked and results manipulated. In fact, this possibility is what informed one of opposition's preconditions for accepting defeat. The condition was that the IEBC opens up its database for inspection by various stakeholders. Of course, they refused as expected. In the meantime, information continued to trade in the public sphere through social media and this explains why the media should be a central object of analysis (Fraser, 1992). In fact, it is in recognition of this almost de-facto power wielded by the media to advance power interests that ensures media coverage during elections becomes an important issue to the extent that it is explicitly captured in our Constitution in clauses related to rights of access to information and press freedom.

In theorizing the public sphere, Jurgen Harbermus argues that different competing groups struggle for consensus to control and dominate a marketplace of ideas. The government, the civil society, pressure groups, citizens, religious leaders, bloggers, citizen journalists, academics and others, were battling it out in Kenya in order to make a conclusive judgment on who won elections and the way forward for the country giving birth to two opposing camps; those who felt the opposition should have accepted defeat and challenged the results through the court, versus those who argued that the court was not an option since its openness to State manipulation as experienced by Raila Odinga in 2013 where the court rejected crucial evidence about vote tampering on technical grounds, meant it cannot be trusted. This media environment has been characterized by disinformation and, more often than not, dominated by propaganda.

The media as a constitutional organ, pressure groups, citizens and politicians all have a role to play in a democracy. After the opposition won the case in the Supreme Court of Kenya through a petition that nullified the presidential results for example, the opposition came up with conditions for reforming the IEBC to pave way for electoral justice through peaceful, free, fair, and credible elections as ordered by the court. Among other demands, they came up with irreducible minimum for them to participate in the repeat presidential elections and they informed their supporters about their demands as listed by Raila Odinga's spokesman Dennis Onyango's ${ }^{17}$ Facebook post in the following excerpt.

\section{Polling Stations}

-IEBC should provide a list of all polling stations and registered voters per all those polling stations in advance. List should indicate the GPS locations of all polling stations and the network coverage.

Returning Officers

-A new slot of returning officers to be appointed for all the 291 constituencies Current serving ROs to remain as Constituency Elections Managers and not play any role as Returning Officers in the fresh elections but provide logistical support to the appointed ROs.

-Appointment of ROs should be from a pool provided by political parties of nominees. Posting of ROs should be done through open balloting in public to determine constituencies where the officers are to be posted.

Results Transmission

-No text messaging in sending elections results. Only scanned images are to be sent through the KIEMS kit to the constituency and national tallying center.

-Commission is to proactively announce exact number of persons who have voted at 5 PM based on tabulations

${ }^{17}$ Onyango D. Facebook post on Raila Odinga for President, Facebook Page post. 14 August 2017. 
from KIEMS Kits before the counting starts.

-Elections results are to be announced at the Constituency level. Only scanned images to be sent through the KIEMS kits or results transmitted by Presiding Officers and Returning Officers may be tabulated.

- National tallying center should not display results before they are verified and announced at the constituency level.

- No results should be displayed unless political party and candidates' agents are given full access to all transaction logs and databases.

- National tallying center should only display scanned images of result Forms once publicly announced at the Constituency tallying centers.

-Media Houses should proactively cover all results announcements at the respective constituencies and show live feed of the outcome.

- Candidates' agents should be part of receiving teams at the constituency and national tallying centers. Receiving teams verify all Forms 34As delivered and confirm that accurate entries are made on the Forms 34Bs and sign off before announcement is made.

- Observers should be allowed access to this process.

Complicit Elections Personnel

-A scrutiny of the Forms 34Bs from the constituencies showed that 80 constituency Forms were fake and therefore illegal. Officers who were complicit in processing results through these illegal Forms should not play any role in the fresh electoral process.

-Officers who also facilitated the display of figures purporting them to be results but which at the Supreme Court hearing were disowned by the Commission as mere statistics should equally be barred from participating in the fresh elections.

ICT Infrastructure

-Independent international experts should be engaged to manage the entire ICT framework of the elections with close supervision of the Candidates agents and the IEBC. Results transmission system will be designed on the Oracle platform and overseen by Oracle Consulting. No use of cloud servers in results transmission. IBM was contracted to provide end to end security testing of the KIEMS system. IBM is allowed to provide security and monitoring of users, networks, and servers used in results transmission.

The IEBC failed to meet these conditions despite pressure from various stakeholders compelling the opposition to withdraw its candidature. The ruling coalition therefore conducted a repeat election in what was described as a charade and a sham by leading international media like al-Jazeera, BBC and CNN judging from the low voter turnout projected at 28 percent by BBC and 27 percent by CNN. Locally, it was seen as competition between Uhuru and Kenyatta (self-competition) with all sorts of humour riddling it as shown in the following examples from Facebook:

Angu Charity: ${ }^{18}$

Hope the whole world now knows that Meru people never buttlick Uhuru Kenyatta.

The voter turnout was pathetic!

${ }^{18}$ Charity, A. Facebook post. October 27th 2017, 11:00 AM. 
The silent majority are for Rao.

Uhuru Kenyatta must go!

Raila Odinga For President 2017-The Kenya We Want

Bettern Chero: ${ }^{19}$

BITTER TRUTH RAILA BOYCOTT UNMASKED

1. Kikuyu aren't the majority in Kenya Luhyas are but Kikuyu have access to the instruments of power to manipulate real truth.

2. Kiambu doesn't have 2.1 million voters it's a manipulated figure, yesterday Kikuyu truly voted how voter turnout turned less $600 \mathrm{k}$ it's only the devil that can explain.

3. Uhuru never got 8.4 million indeed devil has ashamed him, Kikuyu and our Kalenjin voted in numbers as they did August it's shocking that only 6 million votes they reached, this has exonerated Raila and Mudavadi who said Uhuru had 6.4 million Raila had 8.1 ukweli uwazi now [the truth is out now].

4. IEBC and Jubilee said there were over 1.6 million from central Kenya who only voted the president but never voted other candidates from MCA [Member of County Assembly] to governor, so where did this people go yesterday??

5. There was nearly 165,000 votes from Nyamira County is it magic it went to less 10,000? Kajiado County Jubilee had nearly half a million is it magic now less $100 \mathrm{k} ?$

6. Bungoma County Jubilee outshined NASA sasa[now] what happened yesterday Jubilee was ashamed with less 100k recall we have two Sabaot Kalenjin constituencies in Bungoma contributed near 80,000 votes...

In general IEBC [Independent Electoral Commission] was JEBC [Jubile Electoral Boundary Commission] and indeed truth imejidihiiza hapa pole kidogo [has come out here am sorry]. Government manipulated IEBC using State power sad... As daughter of the soil from beautiful hills of Sacho and KANU [Kenya Africa National Union] maestro I never whatsoever stomach lies and mediocrity, ethics drives me not ethnicity and stupid propaganda.

Clement Wamwaya: ${ }^{20}$

Where is $70+1$ Baba has numbers and I want to congratulate [sic] our brothers and sisters From Makueni County, Kitui County, Narok, Mombasa, Nairobi, Kakamega, Busia, lastly Green Army from former Nyanza province counties for their loss of life for protecting our victory.

Favour Okinyi: $:^{21}$

Well said I support. Ati [So] now they want dialogue. Shame on them after stealing elections and murdering innocent Kenyans who are unarmed demonstrators.

\section{Dialogue? The Quest for Electoral Justice}

But it was the swearing in of the People's President that was controversial and interesting and as charged supporters, largely from opposition strongholds, trooped to Nairobi's Uhuru Park or Freedom Park for the ceremony on 30 of January 2018 for the event, it had already been outlawed by the government and the venue shut down by heavy security presence. However, this did not deter opposition of supporters from trooping in, it was clear that there was no amount of State intimidation that could match the people's resolve to swear in Raila

${ }^{19}$ Chero, B. Facebook post, October 27th 2017, 11:01 AM.

${ }^{20}$ Wamwaya, C. Facebook post, October 27th 2017, 11:03 AM.

${ }^{21}$ Okinyi, F. Facebook Post. October 27th 2017, 11:10 AM. 
Odinga as part of the grand strategy to bring electoral justice in Kenya. By this time, the government through the Communications Authority of Kenya (CAK) had already switched off four privately owned mainstream media stations: Citizen TV, Nation TV, Inooro TV, and KTN News, leaving on-air the National Broadcaster, Kenya Broadcasting Corporation (KBC) which is largely a mouthpiece of the State and K24, owned by politicians in government in a clear strategy that betrayed their "good intentions". The government claimed the closure was for "national security" interests.

It is hear that we see the State determined to use propaganda not only to discredit the swearing in as a non-issue, but to miss-inform the public in order to intimidate opposition leaders and their supporters. In this controversial move, the interior Cabinet Secretary Fred Matiangi, chaired a high profiled security meeting with media managers warning them against covering the swearing in, but, paradoxically, allowed the event to take place later, even going as far as withdrawing security officers who were sent to seal off the venue. It is important to note that only when the media managers defied the nonsensical directive on live broadcasting that their stations were shut down. However, they still went live through online streaming, a move that angered the State inviting a blanket total media shutdown. The latter was prolonged despite High Court's order that gave the stations temporary reprieve pending the determination of the legality of the action on the 14th of February 2018 (the swearing in).

The information vacuum that was created gave room for propaganda to thrive where social media took the lead in circulating information. For example, the government peddled information through $\mathrm{K} 24$ and $\mathrm{KBC}$ and their own social media platforms that the opposition was divided on the oath-taking event after three apposition principles failed to show up for the swearing in including Odinga's running-mate and Deputy President elect, Kalonzo Musyoka, who was to be sworn in alongside the People's President. The truth about their absence was unclear but various sources, including the three principals, indicating that it was a tactical move for security reasons and for the survival of the opposition. Kalonzo Musyoka was quoted on Daily Nation 02 February 2018 arguing that this was part of their grand plan:

The decision [to skip the swearing in] was made in Machakos during the People's Assembly launch two weeks ago when our brother Raila told us we all know what you are dealing with, what you are going through and even the threat to your personal and family safety, you are my deputy, but I want to swear in before you...that was a tactical decision...even if we had ended up at Uhuru Park, which was not possible, honourable Raila would have taken the oath alone. ${ }^{22}$

The State was clearly on a mission to split the opposition and undermine its road-map to electoral justice. If the state was not threatened by People's Assemblies and the swearing in that ensued, then why did it shut down the media and conduct a crackdown against opposition leaders? In a press briefing by the opposition after the release of Ruaraka MP TJ Kajwang, who administered oath to the People's President, by the Milimani Law Courts, NASA held a press conference and threatened to call for mass action "to bring back sanity in the country against a dictatorial regime out to use security forces to intimidate and even eliminate political opponents". The government went further to depot its own citizen Miguna Miguna, one of the controversial lawyers involved in the parallel swearing-in with dual citizenship, back to Canada even after the High Court issued two orders to free him unconditionally and awarded 7 million shillings to compensate him for illegal deportation. The opposition accused the government of acting against the constitution and other legal

${ }^{22}$ Langat P. 2018. "NASA explains Kalonzo's Absence at 'swearing-in event'.” DN 2 February 2018. 
frameworks by closing down leading television stations and arresting opposition leaders arbitrarily. In a tweet widely circulated on social media by the self-declared National Resistance Movement (NRM) general, Miguna Miguna, state intimidation and arbitrary arrest was evidenced. Miguna tweeted:

They [police] have bombed their way into my house and broke up everything! They are still hear!!! they probably want to kill me! [Miguna]. They are searching all rooms. It's an assassination squad! I can't speak. They are still hear looking for me. We need our youth hear in huge numbers. My house is number 486 Runda Meadows!!! It's urgent and dire. ${ }^{23}$

\section{Conclusion}

As China positions itself strategically through its relations with other countries especially those in Africa, to challenge US global hegemony, Kenya, through its non-alignment policy in international relations, has emerged as one of the new battlefields where global power transition between the two biggest economies in the world is taking shape at least at the trade level for now. While the US might be sceptical about future global balance of power, in terms of maintaining the status quo, if China were to replace them as the global hegemon, this has not stopped them from finding ways of cooperating with China especially in the economic and financial spheres, the current trade war notwithstanding. However, when it comes to China dealings in Africa, Washington is raising a red flag and warning African states over China's debt diplomacy for purposes of re-position and rebranding itself in the continent as a more genuine partner in African affairs and consequently countering Chinese influence evidenced in the level of interest the US has shown in successive elections in the country in contrast with Chinese political and economic policy of non-interference in domestic affairs of African States.

The media is at the forefront of this geopolitical power-game where right-wing populism is being given prominence through ideas such as America first, Brexit, and radical nationalism in North America and Europe giving birth to xenphobia, Islamophobia, and discrimination based on racism as Africa continues to be on the receiving end or in the words of Trump, "Shit hole". America first, which could also mean Kenya first depending on the subjective position (radical nationalism), has led to one of the worst trade wars between the world biggest economies (the US and China) which is not good news for international trade and global financial stability. Beijing has warned of increased protectionism and unilateralism at the expense of multilateralism and free market in global affairs and argued that the world is faced with a choice between co-operation and confrontation (Cartesian dualism) while Washington is busy courting news allies in the EU and Africa in the current trade wars and experts are now predicting an inevitable conflict between the two biggest economies in the world.

In this context, Africa seems to be the new kid on the bloc enjoying attention from both China, the US, and European Union and it will depend on how Africa takes advantage of this opportunity for a true African take-off and not take-over by the Chinese as the US has warned. Like the global media, the media in Kenya seemed to be supportive of broader socio-economic and political forces locally and internationally buying the support of misguided hypocritical views from elites, disguised as human rights and democracy as exported to Africa, if the 2017 Kenyan election is anything to go by.

Where China seems to have scored is when the West seemed to have lost direction in terms of influencing electoral reforms in individual African states as part of their broader neoliberal human rights agenda ushering in

${ }^{23}$ Miguna Miguna 2 Feb. 2018. 
an era of state impunity in Kenya in a manner that continues to celebrate right-wing populism vested interests in the continent anchored on corruption, ethnicity and disregard for human rights. Such a contention in Africa seems to betray the role of the West on the continent and perhaps paves the way for African countries like Kenya to look East with interest as Beijing subliminally takes over Nairobi with unconditional loans that would serve the interests of corrupt government officials. It is little wonder, therefore, why China has infiltrated the political-economy of countries like Kenya, Djibuti, Malawi and counting with the unsustainable lagasse to a level that has attracted envy and condemnation from the global hegemon (the USA). This paper concludes by asking a moral question: are Western countries genuine in their pursuit for peace and security, democracy, and human rights in Africa or they are agents of the global multinational corporations that seek new markets in emerging economies in Africa as China surges as a credible contender in global hegemony?

In any case, the elections in Kenya have demonstrated their deep rooted hypocrisy in how they have shied away from defending the truth by ensuring there is electoral justice. As for the mainstream media that should have taken the lead as the public watchdog, accusations of them being a lap-dog regarding their conduct in the 2017 controversial elections should not overshadow the defiance witnessed in four mainstream televisions stations that decided to cover the outlawed swearing in of the People's President, Raila Odinga prompting media shutdown by the Communications Authority of Kenya. Such brave actions from determined journalists give keen observers some glimmer of hope regarding the watchdog future of the local media in African journalism and the direction pan-Africanist media scholar would like the media to take in African affairs. The liberal nature of social media exposed through robust anti-regime activism witnessed in the 2017 controversial elections in Kenya demonstrates the power of technology in voicing the subaltern counter-public and expanding the transnational public sphere in democratic societies.

It is now up to different stakeholders to build up and strengthen the local media, including social media's resolve to uphold human rights and democracy by watching against State dictatorial tendencies as the very reason for the media's existence in a democracy. The paper also concludes, judging from the Kenyan story, that days when the State could totally control the entire media are gone and that is more reason why social media is increasingly the new mainstream media in countries like Kenya. Social media is trusted due to the User Generated Content usually composed of a network of friends who have the power to generate and share information and have more or less similar interests and relatively intimately exposed and attached to each other, albeit, in the electronic web. Freedom of the media, which includes all forms of media, as an extension of individual freedom of expression, is perhaps the best measure of democratic advancement and therefore cannot be compromised. Furthermore, Kenya seems to have taken the lead in Africa in exploiting the aspirations of the people (Africans) through taking advantage of the full potential of its ambitious 2010 Constitution through the "People's Assemblies" inspired by Article One of the Constitution of Kenya 2010 giving netizens renewed hope of fighting dictators and despots that have affected African leadership for many decades, natured corruption, nepotism, and tribalism and therein killed the pan-African dream. As far as Sino-Africa relations are concerned, it will not be business as usual. Evidently, Africans would begin demanding more of Chinese responsibility and leadership in matters human rights as witnessed in the current wave of racism against blacks or Africans in China in the context of corona virus. Africa will also continue to submit to pressure from the West to uphold democracy and therein carefully try to balance both Chinese and American interests on the continent. 


\section{References}

Andae, G. (2018). Tough balancing act for Kenya as US and China battle for its heart. Daily Nation Sunday, December 162018.

Feng, Y. (2013). Global power transitions and their implications for the 21st century. Pacific Focus: Inha Journal of International Studies, 28(2), 170-189.

Fraser, N. (1992). Rethinking the public sphere: A contribution to the critique of actually existing democracy. In C. Calhoun (Ed.), Habermas and the public sphere. Cambridge, MA: MIT Press.

Graber, D. A. (2000). Media power in politics. Washington, DC: CQ Press.

Greven, T. (2016). The rise of right wing populism in Europe and the United States: A comparative perspective. Friedrich Ebert Stiftung. Retrieved on15th October 2018 from: www.fesdc.org

Kelly, K. (2018). Why US-Africa reality does not fit the hype. The East African. Saturday December 22 2018. Retrieved on 22 December 2018 from: www.theeastafrican.co.ke

Levi, J. (1987). Declining power and the pre-emptive motivation for war. World Politics, 40(1), 82-107.

McCombs, M., Shaw, L., \& Weaver, D. 1997. Communication and democracy: Exploring the intellectual frontier in Agenda setting theory. Mahwa, NJ: Lawrence Erbaum Associates;

Nagan, W., \& Manausa, N. (2018). The rise of rightwing populism in Europe and the United States. RedFame: International Journal of Social Science Studies, 6(10), 50-57.

Nyere, C. 2020. A Decolonial Perspective on The North Atlantic Treaty Organisation's Invasion of Libya in 2011. Pretoria: Thesis The University of Pretoria. South Africa.Ogenga, F. (2008). The role of the Kenyan media in the 2007 elections. Journal of African Elections, 7(2), 124-135.

Salman, M. (2017). Strategic hedging and unipolarity's demise: The case of China's strategic hedging. Asian Politics and Policy, 9(3), 354-377.

Woosang, K., \& Scott, G. (2015). Power transition theory and the rise of China. International Area Studies Review, 18(3), 219-226. 